\title{
ANALISIS FAKTOR - FAKTOR YANG MEMPENGARUHI UPAYA PENCEGAHAN PENYAKIT JANTUNG KORONER (PJK) DI DESA PANDES TASIKMADU KARANGNYAR
}

\author{
Diyono', Nisma Ayu Ambarwati ${ }^{2}$
}

\begin{abstract}
Coronary Heart Disease (CHD) is still the leading cause of death in Indonesia. The best management of $\mathrm{CHD}$ is primary prevention, but not many people who do well with a wide variety of factors that influence. Objective: (1) know the description of prevention of coronary heart disease (2) Analyze the factors that affect the prevention of coronary heart disease, including age, education level, and the level of knowledge of the CHD disease. Method: analytical research correlational. Subjects 65 people in the village Pandes Tasikamadu Karanganyar. Samples taken purposive sampling. Data were analyzed with Multiple Linear Regression Test using SPSS 18.

Results: (1) In general, respondents are already doing prevention of coronary heart disease as well with an average value of 22.85. (2) Age $(p=0.474)$ and educational level $(p=498)$ did not significantly influence the prevention of coronary heart disease (3) The level of knowledge and perception of coronary heart disease significantly influence the prevention of coronary heart disease (4) perceptions of coronary heart disease is the most influential factor towards the prevention of coronary heart disease $(p=0.001 ; \beta=$ $0.665)$. Conclusions: factors that influence the prevention of coronary heart disease is the level of knowledge $(p=0.015)$ and perception $(p=0.001)$.
\end{abstract}

Keywords: Coronary Heart Disease, Age, Education Level, Knowledge

\section{PENDAHULUAN}

Masalah utama yang mendasari penelitian ini adalah masih tingginya angka kejadian Penyakit Jantung Koroner (PJK) yang ada di masyarakat. Sampai saat ini penyakit jantung koroner masih menjadi penyebab kematian utama di Indonesia. Hasil Riskesdas tahun 2007 menunjukkan PJK menempati peringkat ke-3, penyebab kematian setelah stroke dan hipertensi (Depkes RI, 2007). Berdasar profil kesehatan Jawa Tengah, Penyakit Tidak Menular (PTM) seperti PJK terkait dengan hipertensi masih menempati proporsi terbesar dari seluruh PTM yang dilaporkan, yaitu sebesar 57.87 persen (Dinkes Provinsi Jawa Tengah, 2015). Menurut World Health Organization (WHO) tahun 2005, sebagaimana dikutip oleh Zahrawardani, Herlambang, dan Anggraheny, 2013), jumlah kematian penyakit kardiovaskuler terutama PJK, stroke dan penyakit jantung rematik meningkat secara global menjadi 17.5 juta dari 14.4 juta.

Faktor utama yang diduga menjadi prediktor semakin meningkatnya morbiditas dan mortalitas PJK dewasa ini, adalah faktor ketidakmampuan pasien atau masyarakat melakukan pencegahan faktor risiko PJK (Indrawati, 2014).

Perawat memiliki peran sebagai educator untuk meningkatkan pemahaman klien tentang PJK dan bagaimana melakukan modifikasi faktor risiko agar tercipta pola hidup dan kualitas hidup yang sehat. Hasil penelitian Hardjojo (2012), membuktikan bahwa melalui penyuluhan kesehatan yang dilakukan tenaga kesehatan tentang penyakit PJK dapat meningkatkan pengetahuan dan sikap responden terhadap resiko PJK. Hasil penelitian Nababan (2008), tentang hubungan faktor risiko dan karakteristik penderita PJK di RSU 
Dr. Pirngadi Medan juga menunjukkan faktor yang mempunyai peran atau berkontribusi secara signifikan terhadap kejadian PJK adalah kebiasaan merokok, hipertensi dan stres.

Pada dasarnya intervensi yang paling tepat untuk PJK adalah prevensi primer atau pencegahan dini dengan mengeliminasi faktorfaktor risiko PJK yang dapat diubah seperti kebiasaan merokok, hipertensi, stres dan sebagainya. Namun pada kenyataannya, hal ini belum berjalan secara optimal. Seringkali pasien datang ke rumah sakit atau fasilitas kesehatan lainnya sudah dalam kondisi jelek, sudah sulit untuk diberikan pengobatan, atau bahkan sudah meninggal. Kondisi yang hampir sama juga terjadi di desa Pandes Karanganyar. Menurut data dari kepala Desa Pandes terdapat warga yang menderita PJK sejumlah 2 orang. Lebih lanjut berdasar informasi dari tokoh masyarakat dan kader kesehatan tingkat pengetahuan warga di Desa Pandes mengenai PJK juga kurang dan masih banyak yang mempunyai gaya hidup yang berisiko mengalami PJK, seperti merokok meski bahaya dari rokok telah disampaikan, minum minuman beralkohol dan kurangnya kesadaran akan berolahraga.

Berdasarkan uraian tersebut di atas serta belum adanya penelitian terkait faktor - faktor yang mempengaruhi upaya pencegahan penyakit PJK, maka peneliti merasa perlu melakukan penelitian tentang "Analisis Faktor - Faktor yang Mempengaruhi Upaya Pencegahan Penyakit Jantung Koroner di Desa Pandes, Tasikmadu, Karanganyar.

\section{TUJUAN PENELITIAN}

Menganalisis faktor - faktor yang mempengaruhi upaya pencegahan penyakit jantung koroner, meliputi tingkat pengetahuan penyakit PJK, umur dan tingkat pendidikan.

\section{METODE/DESAIN PENELITIAN}

Penelitian ini merupakan penelitian analitik dengan desain korelasi untuk mengetahui faktor-faktor yang mempengaruhi upaya pencegahan PJK yang meliputi pengetahuan penyakit PJK, umur dan tingkat pendidikan sebagai variabel bebas (independent variable) dan upaya pencegahan PJK sebagai variabel terikat (dependent variable).

\section{POPULASI, SAMPEL DAN TEKNIK SAMPLING}

Populasi penelitian adalah seluruh Kepala Keluarga (KK) di Desa Pandes Tasikamadu Karanganyar yang berjumlah $75 \mathrm{KK}$. Kemudian dengan tabel Krejcie diambil sampel 65 warga dengan kriteria berusia $>40$ tahun dan belum pernah didiagnosis PJK. Sampel diambil secara purposive sampling, kemudian data dianalisa dengan Uji Regresi Linier Ganda menggunakan program SPSS 18.

\section{HASIL PENELITIAN}

1. Karakteristik Responden

Tabel 1. Karakteristik Responden

\begin{tabular}{lccl}
\hline Karakteristik & Kategori & $\mathrm{n}$ & $\%$ \\
\hline Jenis kelamin & Laki - Laki & 29 & 44.62 \\
& Perempuan & 36 & 55.38 \\
Umur & $40-45$ & 35 & 53.85 \\
& $46-50$ & 25 & 38.46 \\
& $51-55$ & 4 & 6.15 \\
Tingkat & $56-60$ & 1 & 1.54 \\
Pendidikan & SD & 13 & 20.00 \\
& SMP & 16 & 24.62 \\
& SMK & 11 & 16.92 \\
& SMA & 12 & 18.46 \\
Tingkat & D III & 5 & 7.69 \\
Pengetahuan & S1 & 8 & 12.31 \\
tentang PJK & Rendah & 0 & 0.00 \\
Persepsi & Tinggi & 57 & 87.69 \\
Ketakutan & Ringan & 0 & 12.31 \\
Terkena PJK & Sedang & 11 & 0.00 \\
Upaya & Berat & 54 & 83.08 \\
Pencegahan & Kurang & 0 & 0.00 \\
& Cukup & 15 & 23.08 \\
& Baik & 50 & 76.92 \\
\hline
\end{tabular}


Dari tabel 1 diketahui :

a. Berdasarkan jenis kelamin maka responden perempuan adalah 55.38\% lebih banyak dari responden laki - laki yang hanya $44.62 \%$.

b. Jumlah terbesar responden adalah pada rentang umur 40 - 45 tahun yaitu sebesar 35 responden atau $53.85 \%$. Sedangkan jumlah terendah adalah pada kategori umur 56 - 60 tahun yaitu sebanyak 1 responden atau $1.54 \%$. Adapun rata - rata umur responden adalah 45.35 tahun.

c. Kategori pendidikan terakhir dengan jumlah terbanyak adalah tingkat pendidikan SMP yaitu sebanyak 16 responden atau $24.62 \%$. Sedangkan jumlah yang paling sedikit adalah pada kategori tingkat pendidikan Diploma III (D III) sebesar 5 responden atau $7.69 \%$.

d. Mayoritas responden memiliki tingkat pengetahuan tentang penyakit jantung koroner adalah pada kategori sedang yaitu 57 responden atau $87.69 \%$. Diikuti kategori tingkat pengetahuan tinggi 8 responden atau $12.31 \%$ dan kategori rendah tidak ada atau $0 \%$.

e. Mayoritas responden mempunyai ketakutan terkena PJK pada tingkat berat atau sangat takut dengan jumlah 54 responden atau $83.04 \%$, cukup takut atau ketakutan sedang 11 responden atau $16.92 \%$, sedangkan pada kategori tidak takut sejumlah $0 \%$ (tidak ada).

f. Secara umum atau mayoritas responden sudah melakukan tindakan pencegahan PJK dengan kategori baik yaitu sejumlah 50 responden atau
76.92\%, kategori cukup sejumlah 15 atau 23.08\% responden dan yang kurang tidak ada atau $0 \%$.

2. Pengaruh variabel independen

Tabel 2.

Hasil Uji ANOVA dan R Square

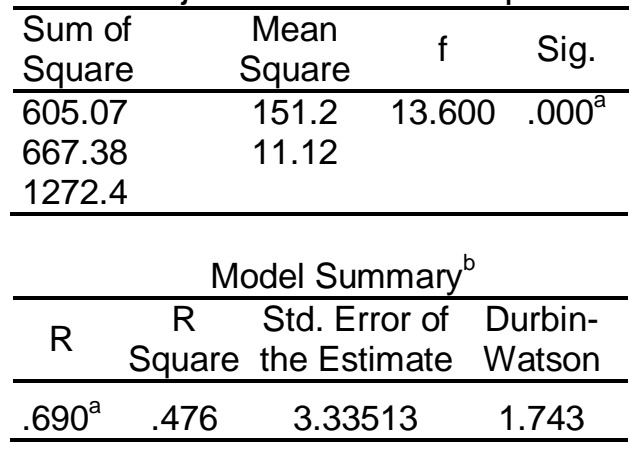

Tabel 2 menunjukkan hasil uji ANOVA nilai $\mathrm{Sig}=0.000(<0.005)$ sehingga dapat disimpulkan bahwa umur, tingkat pendidikan dan tingkat pengetahuan secara bersama - sama berpengaruh terhadap upaya pencegahan penyakit jantung koroner (PJK). Nilai $\quad R$ Square 0.476 memberikan informasi bahwa variabel umur, pendidikan, pengetahuan dan persepsi memberikan kontribusi terhadap upaya pencegahan PJK sebesar $47.6 \%$ sedangkan sisanya yaitu $52.4 \%$ dipengaruhi oleh faktor lain.

3. Analisis Regresi Linier Tiap Variabel

Tabel 3.

Hasil Analisa Regresi Linier Pengaruh Tiap Variabel Independen

\begin{tabular}{lccc}
\hline \multicolumn{1}{c}{ IV } & $\beta$ & $\mathrm{t}$ & Sig. \\
\hline (Constant) & & -1.50 & .137 \\
Umur & -.020 & -.21 & .834 \\
Pendidikan & .180 & 1.82 & .073 \\
Pengetahuan & .303 & 3.22 & .002 \\
Persepsi & .665 & 6.79 & .000 \\
\hline
\end{tabular}

Berdasar tabel 3 menunjukkan hasil analisa pengaruh tiap variabel independen, ternyata variabel yang mempunyai 
pengaruh terhadap upaya pencegahan PJK hanya satu variabel yaitu pengetahuan (sig=0.002) dan persepsi sebagai sub variabel dari pengetahuan dengan nilai sig $=0.000$. Sedangkan variabel umur (sig = 0.834) dan tingkat pendidikan ( $\operatorname{sig}=0.73$ ) tidak mempunyai pengaruh yang signifikan karena nilai sig > 0.05. Sedangkan variabel yang paling berpengaruh adalah sub variabel pengetahuan yaitu persepsi dengan nilai Standardized Coefficients Betta ( $\beta$ ) 0.665 lebih besar daripada nilai untuk pengetahuan yaitu 0.303 .

\section{PEMBAHASAN}

1. Pengaruh Umur Terhadap Upaya Pencegahan PJK

Hasil penelitian ini menunjukkan umur tidak berpengaruh secara signifikan terhadap perilaku pencegahan penyakit jantung koroner, dengan hasil Uji ANOVA adalah sig $=0.834(>0.05)$. Hasil tersebut menunjukkan bahwa tidak ada perbedaan dalam upaya pencegahan penyakit jantung koroner berdasar umur. Menurut Syamsudin (2011), secara umum terdapat 7 (tujuh) faktor risiko dari PJK, salah satunya adalah pria > 45 tahun dan wanita > 55 tahun. Teori tersebut juga hampir sama dengan teori menurut Kabo (2008), yang juga menyebutkan faktor risiko PJK yang tidak dapat diubah salah satunya adalah usia yaitu laki-laki umur $>40$ dan perempuan sebelum menopause umur $>50$ tahun. Menurut Kasron (2012), umur merupakan faktor risiko yang tidak dapat diubah.

Seiring dengan bertambahnya umur, maka semakin banyak pula informasi dan pengalaman yang diperoleh seseorang. Informasi dan pengalaman tersebut kemudian akan menambah $\begin{array}{lr}\text { khasanah pengetahuan } & \text { yang } \\ \text { kemudian juga } & \text { akan } \\ \text { mempengaruhi } & \text { perilaku } \\ \text { seseorang. } & \text { Menurut } \\ \text { Notoadmodjo } & \text { (2003) }\end{array}$

sebagaimana dikutip oleh Fitriani (2011), salah satu pembentukan perilaku dipengaruhi oleh pengetahuan atau insight, dimana pengalaman dan pengetahuan seseorang tentang suatu obyek dapat mempengaruhi bagaimana seorang individu melakukan tindakan, atau perilaku.

Data empiris hasil penelitian ini juga menunjukkan bahwa hampir semua kelompok umur rata-rata sudah melakukan upaya pencegahan penyakit jantung koroner secara baik. Nilai ratarata upaya pencegahan penyakit jantung koroner pada kelompok umur 40 - 45 tahun adalah 22.94 termasuk kategori baik, kelompok umur 46 - 50 tahun nilai 22.40 kategori baik, kategori umur 51 55 nilai 22.44 kategori baik, dan usia > 55 nilai 29 kategori baik. Nilai rata-rata tiap kelompok umur tersebut hampir sama dengan nilai rata-rata dari keseluruhan responden yaitu 22.85 kategori baik. Data-data tersebut menunjukkan bahwa umur tidak mempengaruhi perilaku pencegahan penyakit jantung koroner. Namun demikian umur merupakan faktor risiko penyakit jantung koroner, sebagaimana terbukti dari hasil penelitian dari Zahrawardani, Herlambang, Anggraheny (2013), dimana usia memiliki hubungan bermakna dengan kejadian penyakit jantung koroner $(p=0.019)$. Hasil ini juga sesuai pendapat dari Cahyono (2008) yang menyebutkan bahwa dewasa ini informasi tentang gaya hidup sehat sudah tersebar luas, tinggal tergantung dari 
individu masing-masing yang melaksanakannya.

2. Pengaruh Tingkat Pendidikan Terhadap Upaya Pencegahan PJK

Hasil penelitian menunjukkan bahwa tingkat pendidikan tidak berpengaruh secara signifikan terhadap upaya pencegahan penyakit jantung koroner. Kesimpulan tersebut diperoleh dari hasil uji regresi linier ganda, dimana nilai $t$ pada ANOVA adalah sig $=0.073(>0.05)$.

Tingkat pendidikan pada dasarnya dapat mempengaruhi pengetahuan dan pengetahuan mempengaruhi perllaku. Hal ini sesuai konsep menurut Budiman dan Riyanto (2014), yang menjelaskan bahwa tingkat pendidikan merupakan salah satu faktor yang mempengaruhi pengetahuan. Pendidikan sebagai upaya untuk mengembangkan kepribadian dan kemampuan di dalam dan di luar sekolah (baik formal maupun nonformal), sehingga mampu mempengaruhi proses pengubahan sikap dan tata laku seseorang atau kelompok pendidikan mempengaruhi proses belajar, makin tinggi pendidikan seseorang, makin mudah orang tersebut untuk menerima informasi. Dengan pendidikan tinggi, maka seseorang akan cenderung memiliki informasi yang lebih banyak, baik dari orang lain maupun dari media massa. Semakin banyak informasi yang masuk semakin banyak pula pengetahuan yang didapat tentang kesehatan.

Peningkatan pengetahuan tidak mutlak diperoleh dari pendidikan formal. Akan tetapi juga dapat diperoleh dari pendidikan nonformal. Pengetahuan seseorang tentang sesuatu objek juga mengandung dua aspek yaitu aspek positif dan negatif. Kedua aspek inilah yang akhirnya akan menentukan sikap seseorang terhadap objek tertentu. Semakin banyak aspek positif dari objek yang diketahui, maka akan menumbuhkan sikap makin positif terhadap objek tertentu. Tingkat pendidikan formil yang dimulai dari sekolah dasar (SD), sampai dengan pendidikan tinggi (D III dan Sarjana) secara umum memberikan bekal ilmu dan pengetahuan sesuai dengan jenjang pendidikan masing masing. Hal ini berbeda dengan pendidikan profesi dimana ilmu dan pengetahuan yang diberikan adalah sesuai dengan profesi masing - masing. Pada penelitian ini membuktikan bahwa tingkat pendidikan formil tidak berpengaruh secara signifikan terhadap upaya pencegahan penyakit jantung koroner, yang artinya upaya pencegahan penyakit jantung koroner adalah sama atau tidak berbeda pada setiap kelompok tingkat pendidikan formil, mulai dari SD sampai dengan pendidikan sarjana. Sedangkan penyakit jantung koroner secara materi tidak diajarkan khusus pada pendidikan formil tersebut. Kondisi ini memungkinkan semua responden dengan latar pendidikan yang berbeda - beda mempunyai upaya pencegahan panyakit jantung koroner yang sama atau tidak berbeda.

Fakta tersebut didukung data pada penelitian ini, dimana pada kelompok resonden dengan pendidikan terakhir SD mempunyai nilai upaya pencegahan penyakit jantung koroner 22.76 termasuk kategori baik. Kelompok tingkat pendidikan SMP nilai 22.81 termasuk kategori baik, kelompok tingkat pendidikan SMA kategori 
baik (nilai 22.75), kelompok pendidikan terakhir SMK nilai 23.54 termasuk kategori baik. Hal ini juga sama dengan kelompok pendidikan terakhir D III nilai 21.40 termasuk kategori baik dan kelompok pendidikan terakhir sarjana mempunyai nilai 23.13 juga termasuk kategori baik. Fakta - fakta tersebut membuktikan bahwa tingkat pendidikan tidak mempunyai pengaruh secara signifikan terhadap upaya pencegahan penyakit jantung koroner.

3. Pengaruh Tingkat Pengetahuan Terhadap Upaya Pencegahan PJK

Hasil penelitian menunjukkan bahwa tingkat pengetahuan tentang penyakit jantung koroner mempunyai pengaruh secara signifikan terhadap perilaku upaya pencegahan penyakit jantung koroner. Kesimpulan tersebut berdasar hasil uji regresi pada komponen nilai $t$ dari ANOVA yaitu nilai sig $=0.002(<$ 0.05 ) dengan nilai Standardized Coefficients Beta 0.03.

Sebagian besar pengetahuan manusia diperoleh melalui mata dan telinga. Dewasa ini sumber media informasi sangatlah banyak. Mulai dari media cetak, radio, televisi dan bahkan melalui media sosial termasuk internet. Pada media - media tersebut juga tidak sedikit yang memberikan informasi mengenai penyakit jantung, terutama cara pencegahan. Selain itu tidak sedikit juga petugas dari fasilitas kesehatan baik pemerintah maupun swasta juga giat memberikan penyuluhan dan bimbingan cara hidup sehat, yang pada dasarnya isinya hampir sama dengan upaya pencegahan penyakit jantung koroner. Sesuai dengan konsep menurut Syamsudin (2011), yang menyebutkan penyakit jantung koroner dapat dicegah melalui upaya perubahan gaya hidup yang sehat. Kucia dan Quinn, ed. (2010) menyebutkan upaya pencegahan penyakit jantung koroner dapat dilakukan dengan cara mengendalikan faktor risiko yang dapat diubah, seperti mengendalikan tekanan darah dan berat badan. Informasi informasi tersebut kemudian akan menjadi suatu pengetahuan, yang kemudian akan menjadi dorongan bagi individu untuk bersikap dan mengaktualisasikannya dalam perilaku. Hal ini sesuai konsep menurut Fitriani (2011), yang menegaskan bahwa perilaku yang mempengaruhi sehat atau tidaknya seseorang dipengaruhi oleh beberapa faktor diantaranya faktor pengetahuan, budaya, lingkungan, faktor keturunan dan faktor pelayanan kesehatan. Di sisi lain menurut Maulana (2007), menyebutkan ada beberapa faktor yang menghambat pembentukan perilaku sehat. Salah satunya adalah faktor internal, yaitu faktor yang berasal dari diri sendiri. Faktor tersebut antara lain pengetahuan, kebiasaan sejak kecil, persepsi diri yang salah terkait faktor risiko seperti umur dengan penyakit, kondisi fisik yang selalu sehat sehingga tidak perlu periksa kesehatan dan sebagainya.

Sesuai konsep tersebut menjelaskan bahwa pengetahuan mempunyai peran yang erat dalam membentuk perilaku seseorang. Semakin tinggi pengetahuan seseorang maka kesadaran, sikap dan perilaku sehat juga semakin baik termasuk dalam upaya pencegahan suatu penyakit seperti halnya penyakit jantung koroner. Hasil penelitian ini memberikan bukti empiris terkait konsep - konsep di atas, dimana 
terdapat perbedaan upaya pencegahan penyakit jantung koroner sesuai dengan tingkat pengetahuan tentang penyakit jantung koroner. Hal tersebut didukung dengan temuan data dimana pada kelompok responden dengan tingkat pengetahan tentang pencegahan penyakit jantung koroner kategori sedang mempunyai nilai rata rata upaya pencegahan 20.75 termasuk pada kategori cukup, berbeda dengan responden dengan kategori pengetahuan tinggi yang sudah melakukan upaya pencegahan pada kategori baik dengan niilai 21.63. Temuan ini juga sesuai dengan hasil penelitian Indrawati (2014), yang menyimpulkan bahwa terdapat hubungan positip antara pengetahuan dengan kemampuan pasien melakukan pencegahan sekunder terhadap faktor risiko PJK atau dengan kesimpulan lain bahwa semakin tinggi pengetahuan pasien tentang PJK maka semakin baik juga upaya yang dilakukan untuk mencegah serangan penyakit jantung.

Hasil penelitian lain terkait pengetahuan adalah pengaruh persepsi tentang penyakit jantung koroner dengan perilaku responden dalam upaya pencegahan PJK. Hasil penelitian menunjukkan persepsi mempunyai pengaruh yang paling signifikan terhadap upaya pencegahan penyakit jantung koroner (Standardized Coefficients Beta 0.665; Sig = 0.001). Nilai Standardized Coefficients Beta tersebut lebih besar dari faktor pengetahuan yaitu 0.303. Seperti halnya pengetahuan, persepsi akan muncul setelah seseorang menyimpulkan suatu stimulus yang diperoleh dari luar. Lebih lanjut menurut Sunaryo (2004), persepsi adalah suatu proses akhir dari pengamatan yang diawali oleh proses penginderaan terhadap stimulus yang diterima oleh panca indera lalu diterjemahkan oleh otak berdasar memori atau pengalaman dan pengetahuan yang telah ada. Hasil penelitian ini cukup menarik, karena ternyata faktor persepsi inilah yang paling berpengaruh terhadap perilaku. Hal ini dapat dipahami bahwa pengetahuan seseorang terhadap suatu obyek dapat bervariasi dari tingkatan yang paling rendah yaitu tahu (know) sampai yang paling tinggi adalah evaluasi (evaluation). Sedangkan persepsi merupakan hasil satu respon yang langsung muncul secara alamiah setelah seseorang mengetahui suatu obyek. Seseorang yang hanya sekedar tahu belum sampai paham apalagi mampu menganalisis dan evaluasi, cenderung belum mempengaruhi apa yang harus dilakukan atau diupayakan, sedang seseorang yang mempunyai persepsi sangat takut dengan penyakit jantung koroner maka langsung bertindak untuk mencegah jangan sampai terkena penayakit jantung koroner. Hal tersebut dibuktikan dengan adanya perbedaan upaya pencegahan yang dilakukan oleh responden, dimana pada kelompok responden yang mempunyai persepsi ketakutan sedang mempunyai nilai rata rata upaya pencegahan PJK sedang (17.73), lebih rendah dari responden dengan kategori tingkat persepsi ketakutan berat yang mencapai 23.89 (kategori baik). Data tersebut menunjukkan bahwa semakin responden takut terkena PJK maka semakin baik mereka melakukan upaya pencegahan PJK. Menurut Sunaryo (2004), persepsi timbul 
secara spontan pada manusia, yaitu ketika seseorang menerima rangsangan atau stimulus dari luar maupun dalam dirinya. Persepsi merupakan sifat paling asli yang merupakan titik tolak dari terbentuknya sikap dan perilaku individu. Persepsi terkadang tidak mampu mewakili keseluruhan dari stimulus yang diterima dan hanya sebagian yang dapat diingat dalam memori saja.

Persepsi biasanya merupakan hasil akhir dari suatu proses analisis penginderaan, oleh karena itu maka persepsi dapat berupa keputusan akhir seseorang yang terwujud dalam bentuk pendapat, sikap, ataupun perilaku, seperti pendapat benar atau salah, positip atau negatif, takut atau berani, cemas atau biasa, perhatian ataupun apatis dan sebagainya. Hal tersebut semakin memperjelas bahwa persepsi memegang peranan penting dalam mempengaruhi perilaku seseorang, termasuk dalam penelitian ini adalah persepsi sangat mempengaruhi perilaku atau upaya pencegahan penyakit jantung koroner.

\section{KESIMPULAN}

1. Secara umum masyarakat Desa Pandes Kecamatan Tasikmadu, Karanganyar, sudah melakukan upaya pencegahan penyakit jantung koroner secara baik.

2. Faktor umur dan tingkat pendidikan tidak berpengaruh secara signifikan terhadap upaya pencegahan penyakit jantung koroner.

3. Tingkat pengetahuan dan persepsi tentang penyakit jantung koroner secara signifikan mempengaruhi upaya pencegahan penyakit jantung koroner.

4. Persepsi tentang penyakit jantung koroner merupakan faktor yang paling berpengaruh terhadap upaya pencegahan penyakit jantung koroner.

\section{SARAN}

1. Upaya pencegahan penyakit jantung koroner dapat dilakukan dengan meningkatkan pengetahuan masyarakat melalui pendidikan kesehatan.

2. Dalam memberikan pendidikan kesehatan tentang pencegahan penyakit jantung koroner, umur dan tingkat pendidikan masyarakat tidak harus dijadikan sebagai pertimbangan utama.

3. Perawat dalam memberikan pendidikan kesehatan hendaknya dapat menggunakan metode yang tepat untuk meningkatkan persepsi atau kesadaran masyarakat, misalnya dengan media audiovisual atau dengan contoh kasus yang nyata.

4. Untuk peneliti selanjutnya, diharapkan dapat melakukan penelitian yang lebih komprehensif tentang faktorfaktor lain yang mempengaruhi upaya pencegahan penyakit jantung koroner, misalnya faktor budaya, status ekonomi, dan sebagainya.

\section{DAFTAR PUSTAKA}

Budiman dan A. Riyanto. 2014. Kapita Selekta Kuesioner Pengetahuan dan sikap dalam Penelitian Kesehatan.

Salemba Medika, Jakarta.

Cahyono, JB.S.B. 2008. Gaya Hidup dan Penyakit Moderen. Penerbit Kanisius, Yogyakarta.

Depkes RI. 2007. Riset Kesehatan Daerah (Riskesda) tahun 2017. Depkes RI, Jakarta.

Dinas Kesehatan Propinsi Jawa Tengah. $2015 . \quad$ Profil Kesehatan Provinsi Jawa Tengah Tahun 2015. URL: 
www.dinkesjategprov.go.id. Diunduh 10 Oktober 2016.

Fitriani, S. 2011. Promosi Kesehatan. Graha IImu, Yogyakarta.

Hardjojo, B. 2012. Analisis Intervensi Penyuluhan Penyakit Jantung KoronerTerhadap Perubahan Tingkat Pengetahuan dan Sikap Pegawai Universitas Terbuka Berpotensi Penyakit Jantung Koroner. URL: httprepository.ut.ac.id2431113 41015.pdf 1217. Diakses tanggal 10 Oktober 2016.

Indrawati, L. 2014. "Hubungan Antara Pengetahuan, Sikap, Persepsi, Motivasi, Dukungan Keluarga Dan Sumber Informasi Pasien Penyakit Jantung Koroner Dengan Tindakan Pencegahan Sekunder Faktor Risiko." http://ejournal.jurwidyakop3.co $\mathrm{m}$ /index.php/jurnalilmiah/articl e/download/192/170. Diakses tanggal 10 Oktober 2016.

Kabo, P. 2008. Penyakit Jantung Koroner. Gramedia Pustaka Utama, Jakarta.

Kasron. 2012. Kelainan dan Penyakit Jantung Pencegahan dan Serta Pengobatannya. Nuha Medika, Yogyakarta.

Kucia, M.A. dan Quinn, T., ed. 2010. Acute Cardiac Care: A Practical Guide For. Blackwell Publishing Ltd., United Kingdom.

Maulana, H.D.J. 2007. Promosi Kesehatan. Edisi I. EGC, Jakarta.
Nababan, D. 2008. "Hubungan Faktor Resiko dan Karakterisitik Penderita Dengan Kejadian Penyakit Jantung Koroner di RSU DR. PirngadiMedan. URL: https3.amazonaws.comacade mia.edu.documents 38161570 08E00743.pdfAWSAccessKey Id=AKIAIWOWYYGZ2Y53UL3 AdanExpires $=1485943024 \mathrm{dan}$ Signature=ZMjS3kqdKZcCZFo Bhw8InHhaPi4\%3Ddanrespon se-contentdisposition=inline $\% 3 \mathrm{~B} \%$. Diakses tanggal 01 Pebruari 2017.

Sunaryo. 2004. Psikologi untuk Keperawatan. Penerbit Buku Kedokteran EGC, Jakarta.

Syamsudin. 2011. Buku Ajar Farmakoterapi Kardiovaskular dan Renal. Salemba Medika, Jakarta.

Zahrawardani, D., S.K. Herlambang, dan D.H. Anggraheny. 2013."Analisis Faktor Risiko Kejadian Penyakit Jantung Koroner Di RSUP Dr Kariadi Semarang". URL: http://jurnal.unimus.ac.id/index .php/kedokteran/article/downlo ad/1341/1396. Diakses tanggal 10 Oktober 2016.

${ }^{1}$ Dosen AKPER Panti Kosala Surakarta

${ }^{2}$ Mahasiswa AKPER Panti Kosala Surakarta 